James Anderson, Kiran Bharthapudi, Hao Cao:

\title{
Occupy the Heterotopia
}

\begin{abstract}
:
In this essay, Foucault's concept "of other spaces" - or, heterotopia - is used to examine the Occupy Wall Street (OWS) movement in the context of systemic crisis. Neoliberalism is marked by innovations that amplify and accelerate contradictions, unfolding the false utopia of finance capitalism. Information and communication technologies (ICTs) helped hyper-financialize the economy, enrich banksters and extend inequalities. Conversely, high-tech developments allow for decentralized decision-making and more direct democracy, paralleling the ethics of OWS. New ICTs compress TimeSpace, opening doors for empathic connections, generating conditions for elevation of collective superstructural consciousness. This paper explores how these conditions create - and are recreated by - heterotopic spaces. Drawing on Foucault's method of heterotopology we throw light on the potential of OWS to prefigure another world, analyzing endeavors to promote cooperative autonomy, and raise consciousness in and through mediated environments, always contested, ever in flux, and inevitably over-(but never pre-)determined.
\end{abstract}

\section{Agenda:}

Introduction 152

Occupy Wall Street: Intro to an Occupation of Heterotopia

Emergence of the OWS heterotopia

Neoliberalism: The False Utopia of the State-Finance Nexus.....

OWS Methodology: Heterotopology

First Principle: Heterotopia Exist in Dialectics of Crisis and Deviation 157

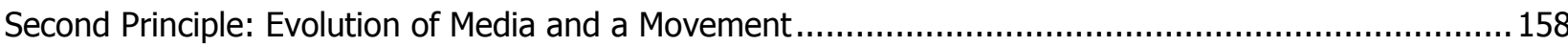

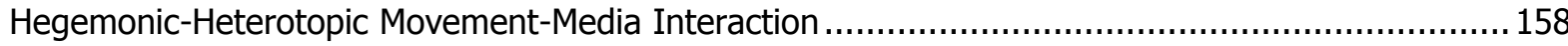

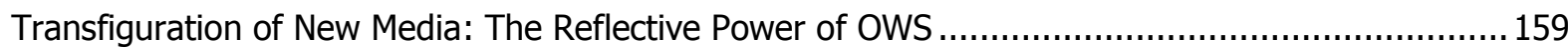

Accelerated False Utopian Contradictions Catalyze Evolution ........................................ 159

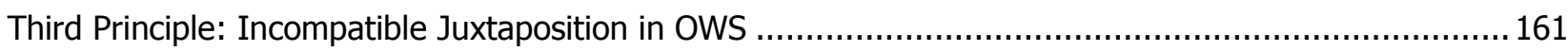

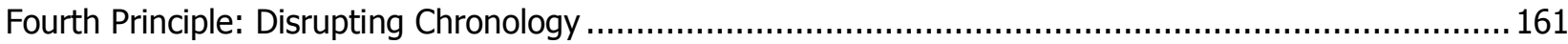

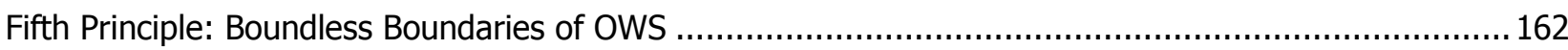

Sixth Principle: Polarization of Wealth and the Unfolding Possibility of Another World ....................... 163 


\section{Authors:}

\section{James Anderson, Ph.D. student:}

- College of Mass Communication and Media Arts, Southern Illinois University Carbondale, Carbondale, $\mathrm{IL}, 62901$

- anderson85@siu.edu

\section{Dr. Kiran Bharthapudi}

- College of Mass Communication and Media Arts, Southern Illinois University Carbondale, Carbondale, IL 62901

- kiran@siu.edu

\section{Hao Cao, Ph.D. student:}

- Department of Radio-Television-Film, University of Texas, Austin, TX, 78712

- haocao.cao@gmail.com 


\section{Introduction}

This paper explores Occupy Wall Street (OWS) as a Foucaultian heterotopia wherein the inextricably linked movement, media and (collective) consciousness interact in different dimensions of TimeSpace. Our discussion is based on the premise that spatiality is of significance to social movements and the scholarship can benefit by recognizing space - specifically, online space - as an active dimension of social resistance against neoliberalism, power and hegemony. ${ }^{1}$ Cyberspace, web addresses, websites, gateways, domains, chat rooms - these are some of the common terms used in the context of the World Wide Web and the Internet. Over the years, we have become accustomed to metaphorically understanding the Internet or the online world as a summation of "virtual" spaces - spaces nonetheless - different from, alternative to and reflexive of "real" or offline spaces. While the debate is far from settled, the Internet and new communication technologies exhibit potential for accelerating and extending social movement praxis, interactively fusing and elevating dissident consciousness and political activism. Internet communication technologies (ICTs) promise to offer alternative public spheres or "virtual spheres" spaces for the development of "radical media." ${ }^{4}$ ICTs can assume the role of radical media for social movements because of their capacity "to prepare the ground for the demonstrations before hand, to enable on-the-ground communication among the demonstrators at the time, to bypass corporate media in order to inform the global public of what had transpired in the confrontation and afterwards, and to facilitate the international discussion of the issue thereafter. ${ }^{15}$

Our project pushes the scholarship further because, we believe, people's use of emergent media can transcend outmoded conceptions of communication technology as mere tools for mobilizing - which, certainly, they are and have been - but now have the potential to mobilize and catalyze superstructural collective consciousness, inseparable from the process of participatory politics. Studies thus far have focused more on the discursive practices that are located in alternative online spaces, for instance, "radical messaging" and "counter informational models" of alternative media. ${ }^{6}$ However, very few studies have discussed the spatial, architectural and superstructural conditions required for alternative discursive practices to operate. In this paper, we focus on the Occupy movement (OWS) and use Foucault's notion "of other spaces," or heterotopias, to examine the spatial (and conceptual) conditions that allow for the movement's discursive practices to operate in/at this historical period of severe systemic crisis. Many informational accounts of OWS have already been written. OWS activists' experiences and reflections have been documented from a variety of perspectives ranging from wealth inequality, political-economic instability, personal debts, home evictions and defecits in democracy. ${ }^{7}$ The Occupy movement has been regarded with mixtures of praise and constructive criticism. ${ }^{8}$ Incisive, historically grounded caustic critiques cynically declare Occupy, for all intents and purposes, dead. ${ }^{9}$ But premature obituaries for OWS often, if inadvertently, reflect out-of-touch perspectives of the power elite, overlooking pockets of (spaces for) resistance that persist. ${ }^{10}$ Failures of OWS are identified using rationalist models that measure

1 Wilton, Robert D., \& Cranford, Cynthia. Toward the understanding of the spatiality of social movements: 374.

2 Papacharissi, Zizi: The virtual sphere: The Internet as a public sphere. 9.

3 Kahn, Kahn., \& Kellner, Douglas: New media and Internet activism: From the 'Battle of Seattle' to blogging. 87.

4 Downing, John: Radical media: Rebellious communication and social movements. 3.

5 Downing, John: Independent Media Centers: A multi-local, multi-media challenge. 215.

6 Rambukkana, Nathan: Is slash an alternative medium? "Queer" heterotopias and the role of the autonomous media. 69.

7 Bryne, Janet: The Occupy handbook.

8 Gitlin, Todd: Occupy nation: The roots, the spirit, and the promise of Occupy Wall Street.

9 Cockburn, Alexander: Biggest financial scandal in Britain's history, yet not a single Occupy sign; What happened?.

10 Hedges, Chris: Occupy will be back. 
movement effectiveness in terms of tangible changes like bargains with policy-makers to enact modestly defined redistribution goals. ${ }^{11}$ Still, critics of OWS even affirm its effectuality in illuminating different symptoms of neoliberal capitalism within the collective psyche. ${ }^{12}$ Advancing existing research, we begin to make better sense of OWS using the concept of heterotopia. This allows for illuminated understanding of movements operating in the context of, and fighting against, neoliberal hegemony. The concept of heterotopia, and Foucault's method for analyzing these alternative spaces, termed heterotopology, has been underutilized in studies of media communication. Moreover, Foucault's schemata begs to be applied to new media and ICTs vis-à-vis movement dialectics. We employ it to emphasize the importance of space - discursive, mediatic and physical - for social movements, OWS in particular. In considering the complex interactions that characterize these spaces and the interplay among actors and cognitions that shapes and re-shapes spatial understandings, we enrich collective understanding of Occupy processes. We thus throw light on how the movement and emergent media reinforce and parallel each other, perhaps prefiguring another world.

\section{Occupy Wall Street: Intro to an Occupation of Heterotopia}

Zuccotti Park was occupied on 17 September 2011. Just as (we contend) OWS potentially prefigures (an)other world(s), it was prefigured by various movements and praxis that preceded it. These include the short-lived Paris Commune of $19^{\text {th }}$ century France; ${ }^{13}$ revolutionary anarchists in 1930 s Spain; ${ }^{14}{ }^{15}{ }^{16}$ worker and student "tomas" (occupations) of factories and schools in Latin America - in Chile ${ }^{17}$ and Argentina ${ }^{18}$ in particular; politics of horizontalidad (inclusive, non-hierarchical forms of social relations); ${ }^{19}{ }^{20}$ rhizome structures of knowledge, ${ }^{21}$ ubiquitous networks of social relationships, ${ }^{22}$ and community-oriented workplace democracies operating just below the surface of mainstream consciousness. ${ }^{23}$

We consider it equally important to recall the large-scale protests against the World Trade Organization (WTO) meeting in Seattle in 1999 when the first Independent Media Center (IMC) was created to offer a counternarrative to the mainstream media coverage of demonstrations, giving protesters the chance to confront the corporate agenda in the physical public sphere, and through the cybersphere of still-nascent Internet technology. ${ }^{24}$ Other IMC chapters developed subsequently, often "in response to crisis events such as protests against international financial or policymaking institutions, or corporate entities." ${ }^{25}$ The phenomenon started in the US, but expanded worldwide, connecting localities and nodes of resistance across the globe in a unified yet decentralized manner. The virtual IMC "works in conjunction with physical spaces that function as local nodes of a global network." Downing draws a connexion between the decentralized network of activists and the parallel

11 Roberts, Alasdair: Why the Occupy movement failed.

12 Roberts, Alasdair: Why the Occupy movement failed.

13 Harvey, David: Rebel cities: From the right to the city to the urban revolution.

14 Guérin, Daniel: Anarchism: From theory to practice.

15 Marshall, Peter: Demanding the impossible: A history of anarchism.

16 Sitrin, Marina, \& Azzellini, Dario: Occupying Language: The secret rendezvous with history and the present.

17 McSherry, Patrice: Chilean Students Challenge Pinochet's Legacy. 29.

18 Sitrin, Marina: Horizontalism: Voices of popular power in Argentina.

19 Sitrin, Marina: Horizontalism and the Occupy movements. 74.

20 Sitrin, Marina: Horizontalism: From Argentina to Wall Street. 8.

21 Deleuze, Gilles.,\& Guattari, Felix: A thousand plateaus: capitalism and schizophrenia.

22 Castells, Manuel: The rise of the network society.

23 Alperovitz, Gar: America beyond capitalism: Reclaiming our wealth, our liberty, \& our democracy.

24 Downing, John: Independent Media Centers: A multi-local, multi-media challenge. 215.

25 Brooten, Lisa: The power of public reporting. 239. 
structure of the Indy Media technology/movement, seeing it as intrinsically linked to the socialist-anarchist activist tradition critical of state-corporate power. ${ }^{26}$ The Occupy movement has had, from its very inception, a similar socialist-anarchist predisposition. OWS principles of direct democracy, horizontal general assemblies and opposition to both corporate-financial and state power speak to that same socially-minded autonomous ethos. ICTs and social media tied to the movement further reflect that spirit in organization, form and content. Hence, we argue that it is this anarchist-socialist movement-media counter-site reified by OWS that makes it a viable heterotopia in the Foucaultian sense.

\section{Emergence of the OWS heterotopia}

No one organization or institution can lay claim to Occupy, but it would be historically inaccurate not to point out certain like-minded convergences that got OWS off the ground. Adbusters, a "global network of artists, activists, writers, pranksters, students, educators and entrepreneurs" whose aim is to "advance the new social activist movement of the information age, ${ }^{\prime 27}$ formally put out a call on their online blog on 13 July 2011 . Titled, "\#OCCUPYWALLSTREET," the hashtagged precursor to heterotopic praxis asked, "Are you ready for a Tahrir moment?" and implored all the "redeemers, rebels and radicals out there" to make like "the acamapados of Spain," entreating "On Sept 17, flood into lower Manhattan, set up tents, kitchens, peaceful barricades and occupy Wall Street." 28 "But a meme alone does not an occupation make"; to the point, "An occupation needs people on the ground." 29 The 13 July clarion call, "and a bit of poster art were the extent" of Adbusters' involvement; the anti-consumerist collective "floated the meme and left the rest to others." ${ }^{130}$

After autonomous activists working collectively made ample use of the new mediascape, "hundreds responded," ${ }^{11}$ descending on Zuccotti Park - renamed Liberty Plaza - "to protest the blatant injustices of our times perpetuated by the economic and political elites. ${ }^{\prime 32}$ As of late November 2011 hundreds of cities across the US were Occupied. Thanks to meme proliferation made possible by new media technologies, and a resonant counter-hegemonic message transversing the global social mediascape, the movement took off. Occupy sites set up across the world. ${ }^{33}{ }^{34}$ But this challenge to the neoliberal order would not stand - at least not without counterrevolutionary response and repression. Those occupying Zuccotti Park in New York were evicted in the wee hours of the morning on 15 November $2011 .{ }^{35}$ Since that time most of the OWS physical encampments across the country - and the world - have been evicted, but general assemblies, direct actions, mass gatherings and large demonstrations still take place all the time. The movement lives. But what sociopolitical-economic context birthed it? Why is the movement-media interplay so salient - inextricable even? And why in the hell should OWS be conceptualized as heterotopia in contradistinction to the contemporary capitalist dystopia constantly represented as the indefatigable, immutable utopia of our time?

26 Downing, John: The independent media center movement and the anarchist socialist tradition. 227.

27 Adbusters: About Adbusters.

28 Adbusters: \#OCCUPYWALLSTREET.

29 Schneider, Nathan: From Occupy Wall Street to Occupy Everywhere. 13.

30 Schneider, Nathan: \#OccupyWallStreet is more than a hashtag. Para 4.

$31 \mathrm{Kim}$, Richard: The audacity of Occupy Wall Street. 16.

32 NYC General Assembly: Principles of solidarity. NYC General Assembly \# Occupy Wall Street. Para 1.

33 Occupy Directory. Occupy Directory.

34 OccupyWallSt.org: Another world is possible!

35 Democracy Now: Occupy Wall Street evicted in late night raid; lawyers secure injunction to reopoen Zuccotti Park. 


\section{Neoliberalism: The False Utopia of the State-Finance Nexus}

Occupy cannot be understood apart from the neoliberal project that gave the movement its raison d'être. Older modes of broadcast media circumscribed by institutional commercial imperatives and top-down information flows, propagate(d) the ideology of capitalist utopia. In relation, Foucault surmised, "utopias are sites with no real place. They are sites that have a general relation of direct or inverted analogy with the real space of Society." Neoliberal doctrines obfuscate the dystopian ideological utopia. Lived conditions belie the myth of meritocracy and fallacy of the free market - as if either were noble, in any way egalitarian or even remotely realizable in the first place. Foucault asserts "utopias are fundamentally unreal spaces." ${ }^{136}$. We liken these sites to Beltway media broadcasts that "present society itself in a perfected form, or else society turned upside down." Staid US media represent an orgiastic life world of unlimited opportunity despite this fanciful construction existing almost exclusively within elite mediations, and perhaps in the exclusionary enclaves belonging to a small fraction of the population. To be sure, banksterism abounds. Banksters have had it better than ever living in their bankster's paradise. Reality for a small slice of the population might really seem utopic, provided their orgasmic utopia entails complete lack of empathy for the mass misery induced by neoliberal policies. Displays of elite indifference to the pain inflicted on huge swaths of people by the latest financial crisis, engineered by the state-finance organism, and the cruel consequent effects of what activist and academic Noam Chomsky called "Wall Street gangsterism," ${ }^{137}$ suggest that might not be too far from the truth.

Until OWS, neoliberalism was mostly "masked by a lot of rhetoric about individual freedom, liberty, personal responsibility and the virtues of privatisation, the free market and free trade, ${ }^{\prime 38}$ which offered ideological cover for more "draconian policies designed to restore and consolidate capitalist class power." Accurate accounting of capitalist developments would depict processes of deindustrialization, profit-oriented urbanization, and ceaseless accumulation via displacement and dispossession. ${ }^{39}{ }^{40}$ Candid assessment would assay and assail the capitalist enterprises that spurred the global economic crisis of 2007-2008. It was lacking until underlying power structures, beguiling discourses and empowering technological advancements in networking and communication birthed an "effectively enacted utopia"41 - the OWS heterotopia. Emergent forms of electronic media and non-hierarchical networking made/make the Occupy movement - and another world - possible.

It was technology-supported endless capital accumulation coinciding with multiple deregulatory schemes that led to a series of events triggering the global economic crisis that started around 2007, extended into 2008 and lapsed into 2009 with effects still felt today, portending systemic change, the contours of which remain uncertain. The crisis had myriad causes, some more direct than others. Banks and loan companies lent to consumers to purchase commodities (e.g. credit cards and home mortgages). Investment banks bought the "debt obligations in 'bundles'" worth millions, which were then sorted according to risks that would compromise the flow of interest from which the bundled derivatives were based on. ${ }^{42}$ Those derivatives were sliced and diced to make it easier for financial firms to invest, and some firms offered swaps - a kind of unregulated insurance designed to protect investors if debts go bad. Harvey puts the "mountain of 'toxic' mortgage-backed securities held by banks or marketed to unsuspecting investors all around the world" at the "epicenter of the problem" within this particular interlinked set of events. ${ }^{43}$ Subprime predatory lending practices - predicated on duplicitous rating evaluations and opaque escalating interest rates - put people in homes with mortgages that they (understandably and inevitably) could not afford, breaking the casino-capitalist camel's back and triggering an economic

36 Foucault, Michel: Of other spaces. 24.

37 OccupyWallSt.org: Noam Chomsky announces solidarity with \#occupywallstreet.

38 Harvey, David: The enigma of capital and the crises of capitalism. 10.

39 Harvey, David: Rebel cities: From the right to the city to the urban revolution.

40 Wallerstein, Immanuel: World-systems analysis: An introduction.

41 Foucault, Michel: Of other spaces. 24.

42 Scheer, Richard: The great American stickup.

43 Harvey, David: The enigma of capital and the crises of capitalism. 4. 
chain reaction. Lower level investors who had invested in the "'highly rated' securitised mortgages, found themselves holding worthless pieces of paper, ${ }^{\prime \prime 4}$ and they couldn't meet debt obligations. Major financial institutions were left without the requisite capital, and so public funds were used instead. ${ }^{45}$ Treasury Secretary Henry Paulson, a former president and CEO of Goldman Sachs, ${ }^{46}$ along with Timothy Geithner, a "pro-Wall Street Clinton veteran" 47 and then chairman of the New York Federal Reserve, in collusion with other private bankers and technocrats demanded a $\$ 700$ billion bail-out for the "too big to fail" banks. ${ }^{48}$.

Capitalism took a decisive turn. Bonuses now near the $\$ 50$ million range for major financial players. ${ }^{49}$ Bloomberg reported that bankers took "tens of billions of dollars in emergency loans at the same time they were assuring investors their firms were healthy," and that the Federal Reserve loans gave an estimated $\$ 13$ billion by way of below-market rates to banks, undisclosed to congress. ${ }^{50}$ In 2008 , a full $\$ 7.7$ trillion was funneled "to Wall Street under the table - without one constituent phone call - without worrying about one election - without having to give one explanation." ${ }^{51}$ The OWS chant, "Banks got bailed out, we got sold out," sums the situation up succinctly. When there are 413 billionaires in the US ${ }^{52}$ at around the same time as the number of Americans living in poverty -46.2 million - is the largest in the 52 years since estimates have been available, ${ }^{53}$ and the average college graduate now owes around $\$ 25,000$ in student loans, ${ }^{54}$ hard disparities hit home, reaping apart hegemonic fissures to reveal the facade of capitalist utopia in hitherto unseen and unheard ways. We have have approached "what can only be called a systemic crisis - an era of history in which the political-economic system must slowly lose legitimacy because the realities it produces contradict the values it proclaims." 55 The level of collective critical consciousness elevated to the point the countervailing Occupy heterotopia had to be established.

\section{OWS Methodology: Heterotopology}

Foucault adduced six principles for describing heterotopias. Systematic evaluation using these principles can aid in describing an existing heterotopia. The descriptive method, differentiated from "science because the term is too galvanized now," then "would, in a given society, take as its object of study, analysis, description, and 'reading' (as some like to say nowadays) of these different spaces, of these other places." This "sort of simultaneous and mythic contestation of the space in which we live, this description could be called heterotopology." In the section that follows we analyze and describe OWS in its movement-media totality as a heterotopia using the six principles enumerated by Foucault. ${ }^{56}$

44 Harvey, David: The enigma of capital and the crises of capitalism. 4.

45 Scheer, Richard: The great American stickup.

46 Harvey, David: The enigma of capital and the crises of capitalism. 5.

47 Scheer, Richard: The great American stickup. 223.

48 Harvey, David: The enigma of capital and the crises of capitalism.

49 Harvey, David: The enigma of capital and the crises of capitalism. 15.

50 Ivry, Bob., Keoun, Bradley., \& Kuntz, Phil: Secret fed loan gave banks $\$ 13$ billion undisclosed to Congress. Para 2.

51 Hartmann, Thom: $\$ 7.7$ trillion to Wall Street - anything to keep the banksters happy! Para 1.

52 Harvey, David: The enigma of capital and the crises of capitalism. 15.

53 U.S. Census Bureau: About Poverty - Highlights.

54 Center for Popular Economics: Economics for the 99\%.

55 Alperovitz, Gar: America beyond capitalism: Reclaiming our wealth, our liberty, \& our democracy. 3.

56 Foucault, Michel: Of other spaces. 24. 


\section{First Principle: Heterotopia Exist in Dialectics of Crisis and Deviation}

The first principle of heterotopology, according to Foucault, is "that there is probably not a single culture in the world that fails to constitute heterotopias. ${ }^{\prime 57}$ These sites take different/non-universal forms in different cultures. To provide a timely and prominent example, in relation and in opposition to "free" market system utopias reflecting neoliberal globalization, heterotopias of social protest took variant forms around the world in 2011: riots in London, hunger strikes in India, pro-union demonstrations in Madison, Wisc., and the high profile "Arab Spring" uprisings in the Middle East and North Africa. With regard to the latter, Harb (2011) credits social media with facilitating revolutionary transformation in Tunisia and Egypt, but notes the moment had to be right and enough people had to be receptive for events to take place as they did. ${ }^{58}$ Operating "outside the confines of the centralized structures that make other media profitable but limited in their potential to contribute toward democratic media experiences, ${ }^{\prime \prime 59}$ Internet technology is not "inherently transformative of either human communication or social and political relations," but the interaction among those vectors in specific contexts "constitute the matrix within which we can locate the power of the new media to create new spaces for discourse and coordinated action." ${ }^{\prime 60}$

Echoing the general view of Occupy, we see extant injustice as systemic. Bank bailouts, bonuses for bankers, and austerity for the masses make iniquity as apparent as ever. New ICTs allow for faster, less filtered information dissemination. Contradictions can no longer be adequately concealed by mass media superstructural violence and ideological inversion of reality. Past research shows establishment US media - and this is a bit of a leap, so hopefully we do not lose anybody here - support the establishment. Traditional media in the US are highly consolidated, concentrated, and conglomerated; major media predominantly and consistently cater to elite interests with coverage, content, focus, frames, select sources and omissions. ${ }^{61} 62{ }^{63}$ Following the ascendancy of the neoliberal paradigm from the 1970s onward, these defining features and trends have intensified. That intensification of the neoliberal project gave rise to an effectively enacted heterotopia in OWS.

Understanding OWS as a heterotopia requires understanding how heterotopias have been differentiated. Foucault distinguishes between heterotopias of crisis and those of deviation. The former refer to places "reserved for individuals who are, in relation to society and to the human environment in which they live, in a state of crisis"; the latter are spaces for "individuals whose behavior is deviant in relation to the required mean or norm." ${ }^{64}$ Heterotopias of crisis are, Foucault argues, replacing those of deviation. We see OWS as necessarily embodying both. Neoliberal developments and recent Wall Street tyranny highlight world system crisis. This transitional period, accelerated by unbridled banksterism enabled by emergent ICTs and the epochal procession of monopoly-finance capitalist hegemony, offers new media of resistance. It opens doors for deviation from Orwellian conformity.

Occupy epitomizes (or occupies, as it were) this liminal (crisis) phase of qualitative consciousness elevation. The heterotopia of crisis is also one of deviance, ergo prefigurative of another world that Occupy insists is possible. Of course, OWS did not come out of nowhere, but neither is it some re-hash(tagg)ed envisage of erstwhile social movements. True, the socialist-anarchist sentiment is there. The idea of dissident encampment is not an OWS invention - it has strong ties to storied histories of sit-down strikes and worker occupations mentioned before. Parallels with past movements are important but so are differences. Salient differences

57 Foucault, Michel: Of other spaces. 24.

58 Harb, Zahera: Arab revolutions and the social media effect.

59 Brooten, Lisa: The power of public reporting. 239.

60 Bennett, Lance: New media power: The Internet and global activism. 26.

61 Bagdikian, Ben: The new media monopoly.

62 Hallin, Daniel: The media, the war in Vietnam, and political support.

63 Herman, Edward S., \& Chomsky, Noam: Manufacturing Consent.

64 Foucault, Michel: Of other spaces. 25. 
bespeak "new spaces of autonomous construction," including, we argue, occupation of diverse online platforms constituting a "new landscape that is both physical but also conceptual"65_ points we develop below, momentarily.

\section{Second Principle: Evolution of Media and a Movement}

Foucault's second principle holds "that a society, as its history unfolds, can make an existing heterotopia function in a very different fashion." 66 One could conceptualize even pre-existing media systems as heterotopias, given the media's representation, contestation and inversion of other real cultural sites - all criteria of heterotopia laid out by Foucault. ${ }^{67}$ Further, ICTs and social media, generally speaking, compel the major media system to function differently. But calling these media, old and new, ipso facto heterotopias does little to enrich understanding or aid praxis. For that we must assay the evolutionary constructs in and around OWS heterotopia.

\section{Hegemonic-Heterotopic Movement-Media Interaction}

First, when reporting on OWS, orthodox media were initially "dismissive, making fun of people involved as if they were just silly kids playing games and so on,"68 echoing the deprecatory theme of trivialization identified by Gitlin when discussing dominant coverage themes for protest movements. ${ }^{69}$. Yet, mainstream media coverage of the movement has been mixed. ${ }^{70}$ OWS created a space - or spaces - to challenge the mainstream narrative, disassembling the discursive sites that prop up utopian falsehoods. Prior to OWS there was little critical discussion about capitalism or about the pervasive cartel-like control the financial sector exerts over the global economy. The totalizing taboo of systemic critique temporarily lifted, but the power of elusive, illusory utopia persists. Ideological veils can be difficult to divest. Occupy helped make it possible to openly criticize capitalism, inequality, and (especially) the injustices perpetrated by Wall Street plutocrats almost beyond the pale of analysis before, even among many critical intellectual circles. OWS "changed the entire framework of discussion of many issues. ${ }^{71}$ It transformed dominant media discourse, to a degree.

How and why this was done is integral to understanding OWS, and comprehending the movement as unprecedented heterotopia. Unlike social movements past Occupy paid little mind to the mainstream media because the institution remains ensconced in the system of power - a system considered fundamentally flawed by OWS demonstrators. Instead, OWS focused more on generating its own media content via new alternative platforms. As one protester put it, "We do not need the regular media to get this out at all. We are creating our own media. We use social media. We use livestream. We use YouTube."72

In the sub-section that follows we explore how that prefigurative OWS mindset articulated above constantly reconfigures the modus operandi of media and society in heterotopic praxis.

65 Sitrin, Marina, \& Azzellini, Dario: Occupying Language. 24.

66 Foucault, Michel: Of other spaces. 25.

67 Foucault, Michel: Of other spaces. 24.

68 Chomsky, Noam: Occupy. 69.

69 Gitlin, Todd: The Whole World Is Watching.

70 Chomsky, Noam: Occupy.71.

71 Chomsky, Noam: Occupy. 70.

72 Breslin, Kevin: \#whilewewatch. 


\section{Transfiguration of New Media: The Reflective Power of OWS}

The means by which the Occupy movement accomplished what it did are of immeasurable importance, as is comprehending the necessity and transformative nature of the approach. In a documentary about OWS, Democracy Now! producer Sam Alcoff claimed the corporate media need "a good mirror because they were missing in action'when it came to reporting on events leading to the economic crisis. That notion of media-as-mirror ties directly into the discussion of media, social movements and heterotopia73. Foucault calls the mirror "a sort of mixed, joint experience"- both utopia and "heterotopia in this respect: it makes this place that I occupy at the moment when I look at myself in the glass at once absolutely real, connected with all the space that surrounds it, and absolutely unreal, since in order to be perceived it has to pass through this virtual point which is over there." The same could be said for media. The analogy is not new: other researchers have likened media to mirrors. ${ }^{745}$ Still, the metaphor is especially apt as regards OWS, and it is a conception that transcends more than one mode of analysis. As Lim says "power can act in unpredictable nonlinear ways in cyberspace as in other cultural sites." 76 Downing and Brooten assert too many researchers have "fetishized the Internet" in ways that can only be described as "wildly optimistic."77 On the other hand, emergent media can, and inarguably do, challenge mainstream messages and galvanize social protest. ${ }^{78} 79$ Today's global informational capitalism does feature "wildly optimistic" fetishism, but it is an accelerated commodity fetishism rapidly flowing from hyper-fictitious capital of wanton and unwieldy financial speculation accelerated in the compressed TimeSpace of cybernetic neoliberalism. ${ }^{80}$

The "mixed, joint experience" of the media can compel "me to see myself there where I am absent: such is the utopia of the mirror." ${ }^{11}$ Media discourses in this mode inculcate myths of meritocracy, achievement ideologies and free market fallacies. Such structures of (mis)representation intimate that you too should identify with the status quo and you too can enjoy the benefits conferred upon the barons of industry if only you remain docile, passive and alone in your hapless pursuit of wealth and power, so goes the dystopian neoliberal logic of latestage techno-sutured capitalism-cum-illusion.

\section{Accelerated False Utopian Contradictions Catalyze Evolution}

Today's "integrated world capitalism (IWC), structured through emerging global information systems and new media networks," ${ }^{12}$ comes readymade with contradictions and all manner of possibilities for transforming functions of existing heterotopias.

Decentralized ICT infrastructure is intrinsically imbued with more democratic potential than older media, but that technology does not exist in some utopian dream world; it reifies and reproduces oppressive centreperiphery/core-periphery connexions, amoral appropriations of surplus value, dog-eat-dog worker competition in industrial digital markets, and inequitable power relations antithetical to participatory democracy. Meaningmaking discourse through ICTs can come in sanitized, depoliticized, commodified forms via commercialized,

73 Breslin, Kevin: \#whilewewatch.

74 Brooten, Lisa: 'Media as our Mirror.'

75 Couldry, Nick: Beyond the hall of mirrors?.

76 Lim, Merlyna: The Internet, social networks, and reform in Indonesia.

77 Downing, John D., \& Brooten, Lisa: ICTs and political movements. 538.

78 Ghannam, Jeffrey: Social media in the Arab World: Leading up to the uprisings of 2011.

79 Harb, Zahera: Arab revolutions and the social media effect.

80 Harvey, David: The conditions of postmodernity.

81 Foucault, Michel: Of other spaces. 26.

82 Peters, Michael. Breaking open the digital commons to fight corporate capitalism. Para 1. 
privatized platforms (re)presenting ideologies quite clearly at odds with reality. But ICTs can come to function very differently under the right conditions.

Conditions seem ripe as movement media proliferate online. The OccupyWallSt.org web domain anonymously registered on 14 July became the "main clearinghouse for information about the movement's progress," attracting around 50,000 new visitors early on. ${ }^{83}$ The Occupied Wall Street Journal, Occupied Chicago Tribune, DC Mic Check, Occupied Times of London, Tidal, Occupied Philly Media, and Occupied Stories are only a few of the new media projects expressly affiliated with Occupy (\#OWS Info Tent, 2012). Live video streams (e.g. Global Revolution at globalrevolution.tv; and occupystreams.org), the @OccupyWallStNYC twitter account with more than 124,000 followers, and the locale-specific OWS websites - like the Occupy Wall Street site for all the occupations of New York City and the New York City General Assembly working groups website at http://www.nycga.net - are mainstays transforming the new media heterotopia.

But the OWS heterotopia transcends dimensional boundaries on several planes. Let us be more concrete. One would not normally associate popular social networking platforms with revolutionary fervor, but in the case of Egypt and Tunisia, social media websites like Facebook and Twitter transformed from mere social/cultural forums to become political platforms. ${ }^{84}$ Direct democracy and horizontal decision-making in OWS take place in general assemblies on the streets and get remediated via those otherwise capital-infused social media venues. Facebook has been the top online outreach forum "for the most publicly facing occupy media outlet," OccupyWallSt.org, with $25.28 \%$ of the total visits from August 1, 2011 to March 24, 2012 coming from the social networking site. ${ }^{85}$ Speaking to a crowd at the US Capitol Grounds in Washington, DC - and, importantly, also addressing folks who view the free Occudoc film online in a hyper-mediated mode - comedian Lee Camp synthesized the double dialectic thusly:

And the revolution is not going to wait until after your pilates lesson, or your fucking hair appointment, timtummy-tucker-titty-tilt. And the revolution may not be televised, as Gil-Scott Heron told us, but it will be digitized and posted on Facebook, YouTube, Twitter, and everywhere where real ideas are told, alright. So the revolution apologizes for shitting all over your apathy. Now pick a side. ${ }^{86}$

Battle lines are indeed being draw, but it is the powerful who have thus far been the major perpetrators of violence. OWS protesters have faced "aggressive, unnecessary and excessive police force ... pervasive surveillance of peaceful activity," mass arrests, arbitrary applications of the law, "violent late night raids on peaceful encampments, ${ }^{\prime 87}$ officers wielding their big batons (and definitely not compensating for anything, we are sure) with their "jabbing, hitting and swinging" at protesters, bystanders and journalists ${ }^{88}$ - plus the tactic of repression de rigeur, pepper spray. Images of pepper sprayed victims have gone viral. The mass dissemination - or to put it more appropriately, perhaps, the widespread sharing of videos via social networking sites - permits new forms of hegemonic contestation evincing evolution of mediated OWS heterotopia.

Videos of police brutality - or "riot porn" - generated the most views and website traffic for OccupyWallStreet.org. ${ }^{89}$ Unnecessary use of force is immoral and should be repudiated, but OWS researchers suggest the confirmation of the "riot porn hypothesis" they discovered can be used in the information economy to

83 Schneider, Nathan: \#OccupyWallStreet is more than a hashtag.

84 Harb, Zahera: Arab revolutions and the social media effect.

85 OWSAnalytics: Quantitative analysis of phase one of Occupy Wall Street.

86 Trainor Jr., Dennis: American Autumn: An Occudoc

87 Protest and Assembly Rights Project: Suppressing protest: Human rights violations in the U.S. in response to Occupy Wall Street. XI.

88 Protest and Assembly Rights Project: Suppressing protest: Human rights violations in the U.S. in response to Occupy Wall Street. 75.

89 OWSAnalytics: Quantitative analysis of phase one of Occupy Wall Street. 
buttress the movement. Schaudenfreude zeitgeist notwithstanding, OWS analysts aver: "OCCUPY FACEBOOK!!!" - but do it subversively. ${ }^{90}$ The strategy comports with Occupy Media Outlets working "to build engaged audiences by siphoning traffic away from Facebook by creating fan pages designed to direct traffic towards our [OWS] media," because without further prefigurative praxis, "Clicking 'Like' Won't Change the World." Brooten says "the power of the Internet lies not in the technology itself, but in its capacity as a tool for those working to mobilize bodies into action in locally based yet globally networked places, to challenge the corporate media's representations of not only what is happening, but also what is possible." 91 What would go further to make another world possible is if the "siphoning" of traffic from sites like Facebook corresponds with a siphoning of people from the "self-cannabalizing system" of "catabolic capatalism ... whose insatiable hunger for profit can only be fed by consuming the society that sustains it." ${ }^{\prime 92}$ Evolutionary communication technology can negate necrophilic wizardry of Wall Street finance. Corporate colonization of the mind can be undermined by hyper-mediated social movement heterotopia that, as Lievrouw suggests, can "hack" dominating superstructures of cyber-consciousness. OWS livestream portals posted on Facebook transport people into that performative lifeworld taking place in real time(-space), potentially recon(/pre)figuring systems of being better than before. ${ }^{93}$ What must be continually made clear is that the next layer of ideology needs to be peeled meaning people must come to physically (or more directly) participate in participatory democracy in order for the transient heterotopia to continually evolve.

\section{Third Principle: Incompatible Juxtaposition in OWS}

Foucault characterizes heterotopia as a "single real place" capable of juxtaposing several spaces that are in themselves incompatible. ${ }^{94} \mathrm{He}$ emphasizes the architectural anomalies in a heterotopia, using the example of a theatre (single real place) wherein three dimensional spaces are projected on a two dimensional screen. The Occupy Wall Street website is a space that stations several incompatible spaces within its own overarching domain. For example, OccuyWallSt.org juxtaposes text with pictures and videos, including live streams. Three dimensional motion pictures are embedded on a two dimensional canvas. Further, the website allots room for unreceptive spaces (e.g. text and images) and also for receptive spaces (e.g. chatrooms and blogs). The website has global access and appeal but it also is a space for mobilizing local and neighborhood activism. For instance, the site acts as a wider gateway through which activists from local communities in, say, Phoenix, New Haven or Charlotte, can navigate to their respective portals. Occupied ICT environments extend innate human capacities for individual creativity, communication, understanding, and collaboration. In so doing, mass mobilization against capital and its contradictions in the physical world becomes possible, flowing from elevated empathic awareness. Media and movement co-evolve in synergistic fashion thanks to new cyber-super-"structures of feeling." 95 Heterotopic mediations are thus paralleled and embodied in precepts of "unity in diversity" and consensus-based decision-making occurring in the "incompatible" but intimately shared (or live-streamed, as it were) physical space of the same Occupied heterotopia.

\section{Fourth Principle: Disrupting Chronology}

Foucault approaches heterotopias from a temporal dimension. Temporally, heterotopias open up different "slices of time," i.e. "heterochronies."

90 OWSAnalytics: Quantitative analysis of phase one of Occupy Wall Street.

91 Brooten, Lisa: The power of public reporting. 239.

92 Collins, Craig: Cannabalistic capitalism and green resistance.

93 Lievrouw, Leah: Alternative and activist new media.

94 Foucault, Michel: Of Other Spaces. 27.

95 Williams, Raymond: Drama from Ibsen to Brecht.

96 Foucault, Michel: Of Other Spaces. 27. 
time, heterotopias must break off from such temporal imagination and praxis. "Intimately related to economic inequality is the matter of time," concerning "democracy as well as liberty," with the former becoming "meaningless if people do not have time to participate" - an axiom obvious "from Aristole on," as Alperovitz avers. ${ }^{97}$

If capitalism structures time according to the imperatives of valorization and subjugates people's work/life schedule/mode to the capital accumulation process, heterotopias, in their oppositional struggles, have to bring about different concepts of time.

Foucault provides two ruptures of time consciousness that are at variance with convention. One disturbs traditional chronology by extending time eternally. In this form of heterochronies, different time pieces are juxtaposed together in the same space. In OWS previous movements are not vertically chronologized but juxtaposed together. The 1968 student rebellion, the 1999 WTO protests, and the 2011 Tunisia and Egypt uprisings are re-enacted through this movement. ${ }^{98}$ Despite their temporal differences, all these movements point to the theme of righting economic wrong and justifying justice. Thus, an anachronic sense of time is brought about in and by OWS. This new temporal consciousness conceives time not in a way of linear development. Instead, by invoking past experiences, the line between past and now is blurred and the two enjoy a simultaneous presentmoment within a particular TimeSpace. More importantly, when framed and imprinted in people's mind, such temporal consciousness can also extend to the future and elicit a "prefigurative politics." 99 By resuscitating the past and anticipating the future, the heterotopic OWS crystallizes and eternalizes a temporal consciousness that disrupts current notions of normal capitalist development.

The other form of heterochronies intervenes in the preset course of time flow by accelerating time to the point of transience. In OWS flashmob meditations, hour-long marches, and plaza talks amplified by the People's Mic, the spontaneity of collective action is rediscovered and restored. In lieu of planned strategic acts to achieve particular interest, the short gatherings in various OWS locales or through online clicks take place in unscripted manner in response to a congealed neoliberal reality. It is in the very transitoriness that OWS avoids the caveat of being assimilated into the structure of current chronological/social order. The very idleness of sitting, dancing, or singing on the plaza also demonstrates contempt for a time structure attuned to work day routine entrenched in capitalist society. In this sense, the authentically unpremeditated time-consciousness of OWS revolts against an institutionalized order of time.

Foucault also points out that these two dimensions of time consciousness function constitutively of each other and of a particular heterotopia. Indeed, The OWS movement exemplifies the two forms of heterochronies simultaneously. In its festival, transitory, and fleeting gatherings, the various performances in the OWS heterotopic spaces point to a perennial project of practicing and embodying justice.

\section{Fifth Principle: Boundless Boundaries of OWS}

Heterotopias have a fluid boundary in relation to people in or out of the heterotopic spaces. The liminality of boundary is illustrated a limine by the physical presence of this movement at Zuccotti park, "a privately owned public space." 100 The occupied heterotopic space is both/neither private property and/nor public space. If it were strictly public or private, New York City could have justified an early eviction of the protesters very conveniently on established legal grounds. Due to the ambiguity of such a space, New York City failed to establish grounds to crush OWS initiatives at first and thus provided opportunity for the movement's developmental metamorphosis.

97 Alperovitz, Gar: America beyond capitalism: Reclaiming our wealth, our liberty, \& our democracy. 52.

98 Dean, Jodi: Claiming division, naming a wrong.

99 Downing, John: Radical media: Rebellious communication and social movements.

100 Schrader, Stuart, \& Wachsmuth, David: Reflections on Occupy Wall Street, the state and space. 245. 
Apart from such indeterminate status of the heterotopic space, OWS also (de)establishes an ambiguous membership boundary. Foucault considers that heterotopias grant or deny access only to certain people by imposing visible or invisible limits. Actors can gain access to a heterotopic space by actively tailoring themselves to the heterotopic vision. So, in the viral slogan "We are the $99 \%$," the outrageously rich $1 \%$ is excluded from this heterotopic space while the rest are called upon to join the movement. As a calling to the $99 \%$, OWS opens access to, or even urges, the expropriated and those who seek justice to be engaged in the construction of such a space. Yet, on the other hand, not every one of the $99 \%$ is already in the space. To be included in the heterotopia, an agent needs to actively endorse the project and contribute to it. In the Tumblr collection of images, participants identify themselves with OWS by providing their own versions of expropriation, such as college debt, unemployment, or home foreclosure. ${ }^{101}$

The multilocality of OWS makes it more inclusive than many movements past. In OWS, the physical sites extend beyond Zuccotti park in cities and towns both in the US and across the world - Chicago, Boston, Philadelphia, Paris, London, to name a few. And it is the Internet that further opens up new locations and expands the heterotopic space by offering access to everyone identified with its vision - if they are among the roughly $30 \%$ of world citizens within the realm of global net penetration.

Yet, Foucault also notes that access to a heterotopic place sometimes can mean exclusion of this very space, as "we think we enter where we are, by the very fact that we enter, excluded."102 Here lies the heterotopian paradox. As a counter-vision to the neoliberal reality, heterotopic spaces render the opposition and struggles contained in this space while exerting little impact on the daily operations of a world order the activists try to break off. ${ }^{103}$ In this sense, entering a heterotopia ensures the stability of current neoliberal order, i.e. exclusion of its own revolutionary ideal.

This paradox also prompts us to reconsider the boundary of OWS in relation to the neoliberal reality. Saldanha faults that heterotopia cannot capture the complexity of space and its relation to a totalized version of society. Sharp et al deny the possibility of "divid[ing] space unproblematically into spaces of domination and spaces of transgression." ${ }^{104}$ In this sense, we ask: how can we distinguish the OWS heterotopia and neoliberal realities if they are so enmeshed? One way out of such a dilemma is to consider heterotopias in terms of an idea. Heterotopia is such an idea of space, instead of space per se, as "transient, contestory, plagued by lapses and ruptured sites."105 106 Thus, heterotopias lie not in Zuccotti or any Occupy locales, online or physical. Their lifeblood flows from the practiced ideas of agents. It is in this sense that the self-identified boundary best illustrates the relation of insider-outsider since it is morphing along with the constitution of the movement heterotopia.

\section{Sixth Principle: Polarization of Wealth and the Unfolding Possibility of Another World}

The function of a heterotopia "unfolds between two extreme poles." Heterotopias operate to create space that expose "illusory" spaces, on one hand, and create alternative and "absolutely perfect other places on the other"107 The Internet, by its structural and spatial nature, is a "fantasy domain which describes the way how we should live." ${ }^{108}$ OWS media-in-the-making illustrate these twofold contrasting roles.

101 Dean, Jodi: Claiming division, naming a wrong.

102 Foucault, Michel: Of Other Spaces. 27

103 Saldanha, Arun: Heterotopia and Structuralism.

104 Saldanha, Arun: Heterotopia and Structuralism.2085

105 Genocchio, Benjamin: Discourse, discontinuity, difference: The question of other spaces

106 Saldanha, Arun: Heterotopia and Structuralism.2089

107 Foucault, Michel: Of Other Spaces. 27.

108 Davies, Julia: Escaping to the borderlands. 65. 
To wit, a post appearing on the OWS main hub titled "Another World is Possible" contains an image of a pencil sketch embedded in it. ${ }^{109}$ The sketch depicts a transformed New York Stock Exchange (NYSE) and Wall Street. The pillars of the NYSE, instead of the American flag, are draped in a cloth banner which says "Free Market. Open Daily. All Seasons." The digitized panorama deploys the art of détournement generally, and specifically, to subvert the old order ideology and remediate a possible alternative - a counter-vision, shared in the OWS superstructural "counter-site". The inherently contradictory "Free Market" trope is represented as pun to problematize the mythical Wall Street Weltanschauung that, pre-OWS, performed hi-tech chicanery, ensuring the wealth of the $1 \%$ while leaving the $99 \%$ "free" to fight for the trickle down.

In the street, in front of the NYSE building, there are two lush and muscular trees - fully green. On one side of the street, "organic" farmer's market is busy with buyer dressed casually, without the dark suits or ties. On the other side, a garden with a blizzard of bright, yellow and cheerful sunflowers. The "another world" depicted in the sketch is romantic, dreamy, idyllic, and "absolutely perfect". Further, the text in the blog post reads: "the $1 \%$ can never win; they are (by their own design) hopelessly outnumbered. Another world is not only possible. It is unstoppable."

\section{Conclusion}

Foucault invokes the metaphor of the ship to describe heterotopia as "a floating piece of space, a place without a place that exists by itself that is closed on in itself and at the same time is given over to the infinity of the sea." Indeed, "the ship is the heterotopia par excellence. In civilizations without ships, dreams dry up, espionage takes the place of adventure, and the police take the place of pirates." ${ }^{\prime 10}$ The ship metaphor, then, rightly applies to a social movement like OWS attempting to prefigure another world through constant struggle, participation and evolution sailing toward emancipation. Movements are transitional forms of transportation, taking people to arguably over-determined, but never pre-determined, destinations of more transitions. ICTs and new media today parallel the decentralized, non-hierarchical form and dynamic democratic process enacted in OWS. Emergent media technologies perform ship-like functions like never before in times of crisis and everaccelerating TimeSpace, transporting people to other spaces where they can communicate and connect with others. In salient instances cited above, OWS occupied the media dimension of heterotopia in ways that (potentially) alter the processes of collective superstructural consciousness, providing motor force for the movement. Perhaps this paper has also contributed to that effort in some small, similar way, using heterotopology to describe new connexions and point to present prefigurative processes and possible future configurations. We believe looking at OWS as heterotopia clarifies areas for setbacks, consequences, repercussions and reactionary repression from concentrations of power that would prefer people remain passive, obedient and preOccupied with free market illusions. If neoliberalism has permeated all spheres of social life, pervading collective consciousness, then OWS should be seen as awakening an alternative way of thinking about things. The networked heterotopia wherein OWS discourses perform "counterpower"111 should, as we suggest, be viewed as fertile ground for igniting innate alternative praxis suppressed by normative neoliberal conceptions. Foucault argued elsewhere that emancipatory struggles of movements are more or less about fluctuating assertions of power. ${ }^{112}$ Contrary to the Foucaultian view, those capacities stem from impermanent yet relatively fixed intrinsic faculties of human nature, ${ }^{113} 114115$ as does the impetus to Occupy the heterotopia so as to prefigure another

109 OccupyWallSt.org: Another world is possible!

110 Foucault, Michel: Of Other Spaces. 27.

111 Castells, Manuel: A network theory of power.

112 Chomsky, Noam, \& Foucault, Michel: The Chomsky-Foucault debate on human nature.

113 Chomsky, Noam, \& Foucault, Michel: The Chomsky-Foucault debate on human nature.

114 Chomsky, Noam, \& McGilvray: The science of language: Interviews with James McGilvray.

115 Chomsky, Noam: Language and politics. 
(more just) world that OWS in concert with our analysis of it as heterotpia suggests is possible, although not in any way pre-destined. Here we hope to have laid early theoretical foundation for elevating consciousness, deepening and extending the OWS heterotopia to new scholarly spheres - online, offline and in the mind. Our labor and the essence of the OWS heterotopia cannot be evaluated by the same standards used to assess movements, media and scholarship that sailed in a different era. The significance of the Occupy heterotopia, its media and maiden voyage will probably only be apparent if the ship successfully transverses treacherous neoliberal waters to make it to a place - a new world - characterized by alternative modes of being and perceiving.

\section{References}

Adbusters. 2012. About Adbusters. Adbusters Culturejammer Headquarters. Retrieved July 30, 2012, from http://www.adbusters.org/about/adbusters

Adbusters. 2011, July 13. \#OCCUPYWALLSTREET. Adbusters Culturejammer Headquarters. Retrieved July 30, 2012, from http://www.adbusters.org/blogs/adbusters-blog/occupywallstreet.html

Alperovitz, Gar. 2005/2011. America beyond capitalism: Reclaiming our wealth, our liberty, \& our democracy. Democracy Collaborative Press: Takoma Park, MD.

Bagdikian, Ben. H. 2004. The new media monopoly: A completely revised and updated edition with seven new chapters. Boston: Beacon.

Bennett, Lance. 2003. New media power: The Internet and global activism. In Contesting media power: Alternative media in a networked world, eds Nick Couldry \& James Curran, 17-37. Lanham, MD: Rowman \& Littlefield.

Breslin, Kevin. Director. 2012. \#whilewewatch. [Motion Picture]. US: SnagFilms. Retrieved August 21, 2012, from http://www.snagfilms.com/films/title/while_we_watch

Brooten, Lisa. 2004. The power of public reporting: The Independent Media Center's challenge to the 'corporate media machine'. In Bring 'em on! Media and politics in the Iraq war, eds. Lee Artz \& Yahya R. Kamalipour, 239-254. Lanham: Rowman \& Littlefield Publishers.

—. 2008. 'Media as our Mirror': Indigenous Media in Burma (Myanmar). In Global Indigenous Media: Cultures, Practices and Politics, eds. Pamela Wilson \& Michelle Stewart, 111-127. Duke University Press.

Bryne, Janet. 2012. The Occupy handbook. Boston: Back Bay.

Castells, Manuel. 2000. The rise of the network society. Oxford: Blackwell Publishers.

- 2011. A network theory of power. International Journal of Communication, 5: 773-787. Available online at http://http://ijoc.org/ojs/index.php/ijoc. Last accessed November 2012.

Center for Popular Economics. 2012. Economics for the 99\%. Retrieved August 25, 2012, from http://www.populareconomics.org/economics-for-the-99-bookletzine/

Chomsky, Noam. 1988. Language and politics. (C. Otero, Ed.). Cheektowaga, NY: Black Rose Books. 2012. Occupy. Brooklyn: Zuccotti Park Press.

Chomsky, Noam., \& Foucault, Michel. 2006. The Chomsky-Foucault debate: On human nature. New York: New Press.

Chomsky, Noam., \& McGilvray, James. 2012. The science of language: Interviews with James McGilvray. Cambridge, MA: Cambridge University Press.

Cockburn, Alexander. 2012, July 6-8. Biggest financial scandal in Britain's history, yet not a single Occupy sign; What happened?. CounterPunch. Retrieved November 30, 2012, from http://www. counterpunch.org/2012/07/06/biggest-financial-scandal-in-britains-history-not-a-single-occupy-sign-what-happened/

Collins, Craig. 2012, August 31. Cannabalistic capitalism and green resistance. Truthout. Retrieved August 31, 2012, from http://truth-out.org/news/item/11173-cannibalistic-capitalism-and-green-resistance 
Couldry, Nick. 2003. Beyond the hall of mirrors?: Some theoretical reflections on the global contestation of media power. In Contesting media power: Alternative media in a networked world, eds. Nick Couldry \& James Curran, 39-54. Lanham, MD: Rowman \& Littlefield.

Davies, Julia. 2006. Escaping to the borderlands: An exploration of the Internet as a cultural space for teenaged Wiccan girls. In Travel notes from the new literacy studies: instances of practice, eds. Kate Pahl \& Jennifer Rowsell, 57-71. Clevedon [England]: Multilingual Matters.

Downing, John D. 1984/2001. Radical media: Rebellious communication and social movements. London: Sage.

—_ 2002a. Independent Media Centers: A multi-local, multi-media challenge. In Global Media Policy in the New Millennium, ed. Marc Rayboy, 215-232. Luton, U.K.: University of Luton Press.

—_ 2002b. "The IndyMedia Phenomenon: Space-Place-Democracy and the New Independent Media Centers, " presented at the BOGUES: Globalisme et Pluralisme conference in the University of Québec, Montréal, April 2002. Available online at wWw.er.ca/nobel/gricis/even/bog2001/b2_pr_f.htm. Last accessed in August 2012.

- 2003. The independent media center movement and the anarchist socialist tradition. In Contesting media power: Alternative media in a networked world, eds. Nick Couldry \& James Curran, 227-241. Lanham, MD: Rowman \& Littlefield.

Downing, John D., \& Brooten, Lisa. 2007. ICTs and political movements. In Oxford University Press handbook on information and communication technologies, eds. Robin Mansell \& Roger Silverstone, 537-560. New York: Oxford University Press.

Dean, Jodi. 2011. Claiming division, naming a wrong. Theory \& Event, 14(4). Retrieved September 9, 2012, from http://muse.jhu.edu/journals/theory_and_event/v014/14.4S.dean01.htm/

Deleuze, Gilles., \& Guattari, Felix. 1987/2005. A thousand plateaus: capitalism and schizophrenia. (B. Massumi, Trans.). Minneapolis: University of Minnesota Press.

Democracy Now. 2011, November 15. Occupy Wall Street evicted in late night raid; lawyers secure injunction to reopoen Zuccotti Park. Democracy Now!. Retrieved July 30, 2012, from http://www.democracynow.org/2011/11/15/occupy_wall_street_evicted_in_late

Foucault, Michel. 1986. Of other spaces (J. Miskowiec, Trans.). Diacritics, 16(1): 22-27.

Genocchio, Benjamin. 1995. Discourse, discontinuity, difference: The question of other spaces. Postmodern cities and spaces, eds. Sophie Watson \& Katherine Gibson, 35-46. Oxford: Blackwell.

Ghannam, Jeffrey. 2011. Social media in the Arab World: Leading up to the uprisings of 2011. Report for the Center for International Media Assistance (CIMA). Washington, DC: CIMA. Available online at http://cima.ned.org/publications/social-media-arab-world-leading-uprisings-2011-0. Last Accessed November, 2012.

Gitlin, Todd. 1980. The Whole World Is Watching: Mass Media in the Making and Unmaking of the New Left. Berkeley, CA, Los Angeles, CA \& London, U.K.: University of California Press.

- 2012. Occupy nation: The roots, the spirit, and the promise of Occupy Wall Street. New York: itbooks. Guérin, Daniel. 1970. Anarchism: From theory to practice. New York: Monthly Review Press.

Hallin, Daniel. 1984. The media, the war in Vietnam, and political support: A critique of the thesis of an oppositional media. Journal of Politics, 46, 2-24.

Harb, Zahera. 2011. Arab revolutions and the social media effect. M/C Journal, 14(2). Retrieved March 28, 2011, from http://journal.media-culture.org.au/index.php/mcjournal/article/viewArticle/364

Hartmann, Thom. 2011, December 3. \$7.7 trillion to Wall Street - anything to keep the banksters happy!. Truthout. Retrieved August 31, 2012, from http://truth-out.org/index.php?option=com k2\&view=item\&id=5368:77-trillion-to-wall-street--anything-to-keep-the-banksters-happy

Harvey, David H. 1989. The conditions of postmodernity. Oxford: Blackwell. 2011. The enigma of capital and the crises of capitalism. Oxford: Oxford University Press. 2012. Rebel cities: From the right to the city to the urban revolution. London: Verso. 
Hedges, Chris. 2012, June 18. Occupy will be back. Truthdig. Retrieved November 30, 2012, from http://www.truthdig.com/report/item/occupy_will_be_back_20120618/

Herman, Edward S., \& Chomsky, Noam. 1988/2002. Manufacturing consent: The political economy of the mass media. NY: Pantheon Books.

Ivry, Bob., Keoun, Bradley., \& Kuntz, Phil. 2011, November 27. Secret fed loan gave banks \$13 billion undisclosed to Congress. Bloomberg. Retrieved August, 31, 2012, from http://www.bloom-

berg.com/news/2011-11-28/secret-fed-loans-undisclosed-to-congress-gave-banks-13-billion-in-income.htm/

Kahn, Kahn., \& Kellner, Douglas. 2004. New media and Internet activism: From the 'Battle of Seattle' to blogging. New Media \& Society, 6(1): 87-95.

Kennis, Andrew. 2012, July 18. Mexican student movement confronts vote buying and media bias in wake of contested election results. Truthout. http://truth-out.org/news/item/10414-mexican-student-movementconfronts-vote-buying-and-media-bias-in-wake-of-contested-election-results

Kim, Richard. 2011. The audacity of Occupy Wall Street. The Nation, 293(21): 15-21.

Lievrouw, Leah A. 2011. Alternative and activist new media. Malden, MA: Polity Press.

Lim, Merlyna. 2003. The Internet, social networks, and reform in Indonesia. In Contesting media power: Alternative media in a networked world, eds. Nick Couldry \& James Curran, 217-288. Lanham, MD: Rowman \& Littlefield.

Marshall, Peter. 1992. Demanding the impossible: A history of anarchism. London: HarperCollins.

McSherry, J. Patrice. 2011. Chilean Students Challenge Pinochet's Legacy. NACLA Report On The Americas, 44(6): 29.

NYC General Assembly. 2012. Principles of solidarity. NYC General Assembly \# Occupy Wall Street. Retrieved July 30, 2012, from http://www.nycga.net/resources/principles-of-solidarity/

Occupystreams.org. 2012. Global directory of \#occupy live video streams. Retrieved July 30, 2012, from http://www.occupystreams.org

OccupyWallSt.org. 2011, September 26. Noam Chomsky announces solidarity with \#occupywallstreet. Retrieved July 30, 2012, from http://occupywallst.org/article/noam-chomsky-solidarity/

OccupyWallSt.org. 2012, August 31. Another world is possible! \#S17. Retrieved September 9, 2012 from http://occupywallst.org/article/Another-World-S17/

Occupy Directory. 2012. Retrieved Aug 1, 2012, from http://directory.occupy.net

OWSAnalytics. 2012. Quantitative analysis of phase one of Occupy Wall Street. Retrieved Aug 4, 2012, from https://docs.google.com/a/siu.edu/presentation/d/1spXu_uuSJXtYKvyWr_MpWXGXW3LCd7_q1HtK4aCuS1M/present?pli=1\&ueb=true\#slide=id.p18

Papacharissi, Zizi. 2002. The virtual sphere: The Internet as a public sphere. New Media \& Society, 4(1): 927.

Peters, Michael A. (2001). Poststructuralism, Marxism and neoliberalism: Between theory and politics. Lanham, MD: Rowman \& Littlefield.

Peters, Michael A. 2012, July 15. Breaking open the digital commons to fight corporate capitalism. Truthout. Retrieved August 25, 2012, from http://truth-out.org/news/item/10264-global-information-systems-education-and-new-media-networks

Protest and Assembly Rights Project. (2012). Suppressing protest: Human rights violations in the U.S. in response to Occupy Wall Street. International Human Rights Clinic. Retrieved July 26, 2012, from http://harvardhumanrights. wordpress.com/2012/07/25/suppressing-protest-human-rights-violations-inthe-u-s-response-to-occupy-wall-street/

Rambukkana, Nathan. 2007. Is slash an alternative medium? "Queer" heterotopias and the role of the autonomous media. Affinities: A Journal of Radical Theories, 1(1): 69-85.

Roberts, Alasdair. 2012. Why the Occupy movement failed. Public Administration Review, 72(5): 754-762.

Saldanha, Arun. 2008. Heterotopia and Structuralism. Environment And Planning A, 40(9): 2080-2096. 
Scheer, Richard. 2010. The great American stickup: How Reagan Republicans and Clinton Democrats enriched Wall Street while mugging Main Street. New York: Nation Books.

Schneider, Nathan. 2011a. From Occupy Wall Street to Occupy Everywhere. The Nation, 293(18): 13-17.

Schneider, Nathan. 2011b. \#OccupyWallStreet is more than a hashtag. Waging Nonviolence. Retrieved July 30, 2012, from http://wagingnonviolence.org/2011/09/occupywallstreet-is-more-than-a-hashtag/

Schrader, Stuart, \& Wachsmuth, David. 2012. Reflections on Occupy Wall Street, the state and space. City, 16(1/2): 243-248.

Sharp, Joan P., Routledge, Paul, Philo, Chris., Paddison, Ronan. Eds. 2000. Entanglement of power: Geographies of domination/resistance. London: Routledge.

Sitrin, Marina. 2006. Horizontalism: Voices of popular power in Argentina. Edinburgh, Scottland: AK Press. (2012a). Horizontalism and the Occupy movements. Dissent, 59(2): 74-75. (2012b). Horizontalism: From Argentina to Wall Street. NACLA Report on the Americas, 44(6): 8-11.

Sitrin, Marina, \& Azzellini, Dario. 2012. Occupying Language: The secret rendezvous with history and the present. Brooklyn: Zuccotti Park Press.

Trainor Jr., Dennis. Director/Producer. 2012. American Autumn: An Occudoc [Motion Picture]. Retrieved August 21, 2012, from http://www.occudoc.org

U.S. Census Bureau. 2012. About Poverty - Highlights. Retrieved August 31, 2012, from http://www.census.gov/hhes/www/poverty/about/overview/index.htm/

Wallerstein, Immanuel. 2004. World-systems analysis: An introduction. Durham: Duke University Press.

Williams, Raymond. 1969. Drama from Ibsen to Brecht. New York: Oxford University Press.

Wilton, Robert D., \& Cranford, Cynthia. 2002. Toward the understanding of the spatiality of social movements: Labor organizing at a private university in Los Angeles. Society for the Study of Social Problems, 49(3): 374-394. 